\title{
JEWS IN POSTWAR LODZ
}

Close to three and a half million Jews lived in Poland on the eve of the Second World War. They constituted $10 \%$ of the overall and $30 \%$ of the urban population. Only some 380,000 Jews, $10 \%-11 \%$ of the prewar Jewish population, survived the War and the Holocaust. It has been estimated that two-thirds of these survived mostly in the Soviet Union, and one third in camps and in hiding. The Jewish population in Poland in the immediate postwar years was in constant flux. There was an inflow of Jewish returnees from the East and an outflow of Jews to the West. There was also considerable internal relocation. Attempts to resettle and start a new life in Poland were matched by successive waves of emigration. Since not all Jews registered with the Central Committee of Polish Jews (CCPJ), the official representative organization of Polish Jewry, and since there were sometimes "double" registrations as a result of relocation, it has been impossible to establish precise data. In midsummer 1946 the number of Jews living in postwar Poland was at its highest — around 250,000. ${ }^{1}$

More than 200,000 Polish Jews survived the war in the Soviet Union as refugees and deportees. After the war, they, along with other prewar Polish citizens, were allowed to return to Poland. An overwhelming majority took advantage of this opportunity. The first to return were thousands of Jewish soldiers and officers who had entered Poland with General Berling's Army, formed in Russia. Among the Polish-Jewish returnees were also those few who survived in the German-occupied prewar Polish eastern borderlands which had become part of Soviet Russia. The repatriation to Poland was usually conducted in freight train transports. These began as early as 1944 and lasted until the end of July 1946. More than half of these transports disembarked in Lower Silesia, part of the Recovered Lands. Other transports arrived in Upper Silesia and in such major cities as Stettin, Lodz, Kracow and Warsaw. ${ }^{2}$

What was the geographical pattern of Jewish resettlement in postwar Poland? On the whole, Jews settled in large urban centers. This was because of the better economic prospects in the cities and the lack of safety, even outright danger, in the small towns. Even those Jews who 
initially returned to their original towns meaning to settle there, at least for a while, were forced by harsh reality to move to larger cities. A wish to live "among Jews" exerted its impact as well. At the end of 1945, Jews were dispersed among 235 localities all over Poland. This number shrank considerably during the following years. As for major urban centers in postwar Poland, in midsummer 1946, 30,000 Jews were living in Lodz, 20,000 in Stettin, 13,000 in Kracow and 8,000 in Warsaw. Lower Silesia became an impressive center of Jewish population, which at its peak reached $100,000 .^{3}$

The war and the Holocaust severely affected the gender composition of the Jewish population. The ratio of men to women was reversed. Whereas in 1931 there were 109 Jewish females for every100 males, in mid-1946, the ratio of women to men was $45.7 \%$ to $54.3 \%$. The postwar gender composition among Polish Jews was also markedly different from that of the postwar population at large. There were two main reasons for that: the Germans preferred to keep males as a more efficient working force, and among those who escaped eastward in 1939 and survived in the Soviet Union, were more men than women. The age composition of the postwar Jewish population in Poland also differed completely from that of the prewar years. The share of children and the elderly declined sharply and the percentage of those in their twenties and thirties increased. The 10-19 age-group shrank by half, whereas the 30-39 age group doubled in size. At the same time there was a surge in births in the immediate postwar years. Children born in 1946 and early 1947 comprised close to 5\% of the total Jewish population. The postwar increase in the birth rate among Jews is particularly amazing when compared with the much lower birth rate among the general Polish population. ${ }^{4}$

Jews began to leave Poland immediately after liberation. Jewish emigration in the first postwar years, within the framework of the Brichah, the Flight and Rescue operation organized and directed by the Zionists, was mostly illegal. Close to 15,000 Jews left Poland as early as July-August 1945. Nearly 33,000 had left by the end of that year. Close to 15,000 left during the first half of 1946. The emigration's peak was, undisputably, in the months following the Kielce pogrom. Thus, 19,000 Jews left Poland in July 1946, 33,000 in August and more than 12,000 in September. Then the flow tapered off. Only 10,000 Jews left Poland throughout 1947. All in all, around 126,000 Jews, assisted by the Brichah, left Poland in the years 1945-1947. Emigration decreased considerably in the years 1947-1949 and a slight reverse trend even became visible. Thus, 5,000 Jews returned to Poland from DP camps in Germany and Austria in 1947. Whereas close to a quarter-million Jews lived in Poland on the eve of the Kielce events, 
their overall number shrank now to about 100,000. The major centers of Jewish population were still the large cities: 14,000 Jews lived in Lodz, more than 12,000 in Wroclaw, close to 6,000 in Krakow and 5,000 in Warsaw. ${ }^{5}$ The possibility of legal emigration of Jews from Poland to the newly established State of Israel was announced in the early fall of 1949 . As a result, close to 30,000 Jews left for Israel in the years 1949-1951, and the total Jewish population of Poland shrank in early 1952 to slightly over $70,000 .^{6}$

The economic situation of Polish Jews in the immediate postwar years was precarious. If the Polish population at large suffered from material devastation, the surviving and returning Jews actually had to start from scratch. A considerable part of the prewar Jewish property was nationalized by the new regime. The local Polish population grabbed material goods previously owned by Jews when they were deported and annihilated. Most of it was never returned. At the same time, however, both the Polish government and Jewish welfare organizations abroad assisted Jewish survivors. The CCPJ, the Central Committee of Polish Jews, received the first modest government allotment as early as December 1944. Five million Zlotys followed in April 1945. Financial and other support from Jewish organizations in the U.S.A., England and Palestine also started arriving around that time. Most of the financial and material support was provided in the following years by the JDC, The American Joint Distribution Committee. The JDC's overall assistance to Polish Jews in the years 19441949 amounted to 20 million dollars. The Polish authorities seemed to be very interested then in Jewish support from abroad. ${ }^{7}$

Most of the Jewish survivors could not resume their prewar ways of earning a living. Petty commerce and artisanship, a major source of income for Polish Jews before the war, could hardly be practiced on a large scale. Thus, the new postwar circumstances almost completely changed the occupational structure of the working Jewish population. They had to move now into production and administration. Thus, in 1947, more than $46 \%$ of Jewish wage earners worked in industry and mining, more than $18 \%$ in administration, and only $12 \%$ in commerce. Jews, usually barred before the war from state and local offices, were able to occupy now a wide range of positions in the state administration, in academia, in the army and in the security apparatus. Jewish students were accepted by institutions of higher learning. In the immediate postwar period there was still a possibility to set up private workshops, and some Jews returned to traditional prewar Jewish occupations such as tailoring, shoemaking and furriery. In time, however, these and other crafts were organized into cooperatives, encouraged by the new regime ${ }^{8}$ 
The Jewish cooperative movement in postwar Poland was, at least for a few years, a success story. Whereas in 1946, only slightly over 100 Jewish cooperatives employed more than 2,000 workers, in 1949, there were 220 Jewish cooperatives with 9,000 workers. Numerous Jewish cooperatives were located in such cities as Lodz, Stettin and Wroclaw. Most of the financial backing came from the JDC and the Polish Government. Eventually, however, these cooperatives employed a growing number of non-Jews and were merged with the state cooperative system. ${ }^{9}$

Official Polish attitudes and policies towards Jews were not clearly defined in the immediate postwar years, and at times they were adopted on the run. However, the pro-Communist, and later outright Communist, regime in Poland was on the whole quite accommodating towards the Jewish minority. The positive attitudes and policies were motivated by both ideological and practical considerations. Polish Socialists and Communists always believed in equality, regardless of ethnic, national and religious affiliation. The fact that the world at large became sensitive to Jewish needs in the wake of the Holocaust had its impact on the Polish authorities as well. Individual Polish Jews, and the Jewish community as a whole, were assisted by the authorities in their postwar attempts towards recovery. The existence of a wide range of Jewish organizations and institutions was allowed throughout the second half of the 1940s. Contacts with Jewish organizations in the West, as well as financial and material assistance from abroad, were tolerated. The new regime in Poland, following Soviet foreign policy interests, also supported the establishment of a Jewish State, and allowed semi-legal, and later legal, emigration of Polish Jews, most of whom ended up in Palestine/Israel. ${ }^{10}$

The major Jewish framework in postwar Poland, considered by the authorities as the representative of Jewish interests, and regarded by Jews as an address for their needs and concerns, was the CCPJ, the Central Committee of Polish Jews. It had been established as early as the fall of 1944, and was supervised, as were other Jewish organizations, by the Ministry of Public Administration. The CCPJ was meant, actually, to operate as an intermediary between the state bureaucracy and the Jews. It was also clear from the outset that the Committee was considered by the government a significant and useful means for mobilizing foreign aid for Polish Jews. The CCPJ's support was also used by the new regime against its ideological and political opponents in the West.

The Committee's leadership consisted of representatives of most of the Jewish political parties, and some Jewish organizations active in postwar Poland. Thus, in 1946, the Committee Presidium consisted of 13 Zionists, 6 Communists, 4 Bundists and 2 representatives of The Union of Jewish 
Partisans. The Zionists usually formed a majority. Since the Committee leadership represented a coalition of parties with differing ideologies and interests, it could not avoid conflicts and frictions, in most cases resulting in compromises. A basic and ongoing contention was between those who supported the idea of rebuilding Jewish life and a Jewish community in postwar Poland and those who saw emigration to Palestine/Israel their ultimate goal.

The CCPJ ran a network of regional and local committees active in the centers of Jewish population throughout the country. The CCPJ's activities were conducted and supervised by a number of departments, such as the Department of Registration and Statistics, the Department of Culture, the Youth Department and the Department of Health and Social Welfare. The CCPJ Youth Department supported, among others, the bursy, boarding centers for young Jews studying in universities and other institutions of higher education. It helped in the establishing and funding of landsmannschaftn, hometown societies, quite popular in the immediate postwar period. The Committee also organized and supported Jewish self-defense in times of danger. ${ }^{11}$

Although the Jewish population of postwar Poland was at its highest less than $10 \%$ of its prewar size, the number of revived Jewish political parties was nearly the same as before the war. The majority were Zionist-oriented, and enjoyed a wide-ranging support among the Jewish population. The largest Zionist party was Ichud, Unity, close in its leanings to the prewar center-right General Zionists. It had 7,000 - 8,000 members in 1947. On the left of the ideological and political spectrum were the Right and Left Poalei Zion parties, whose membership was 3,000 and 2,000 respectively. They merged in late 1947. The Marxist-Zionist youth-oriented Hashomer Hatzair had 1,500 members. All Zionist parties were affiliated with their respective youth movements, which were very popular among Jewish youth in postwar Poland. Most of them cooperated within the Hehalutz-Pioneer framework. ${ }^{12}$

The socialist Bund, a major political force in prewar Poland, lost most of its social base in the Holocaust. After the war it hoped for a close cooperation with the PPS, the Polish Socialist Party. However, with the increasing influence of the Communists, and the final merger of the PPS with the PPR, the impact of the Bund among Poland's Jews became increasingly marginal. When still active, in 1947, the Bund had 1500 members. The Bund leadership consisted mostly of prewar activists who survived in hiding, in camps or in the Soviet Union. Its youth movement, the Tsukunft, consisted predominantly of youngsters from traditional Bundist families. The Bundists shared with Jewish Communists the belief 
that there was a future for Jews in Poland, and opposed the Zionist stand on emigration to Palestine/Israel. In the cultural sphere, Bundists traditionally supported Yiddish and opposed Hebrew. They vehemently opposed "train station agitation" conducted by Zionist parties and youth movements among freshly arrived Jewish returnees from Russia. Bundists accused Zionists of deliberately causing a state of panic among Polish Jews, in order to promote flight and emigration. Hopes nurtured by the Bundists in respect to Jewish life in postwar Poland, were crushed by the Kielce pogrom and by the onset of Stalinism. ${ }^{13}$

Besides Communist leaders of Jewish origin, active mostly in the higher ranks of the party, the government and the security apparatus, Jewish Communists with a strong Jewish identity and specifically Jewish interests were represented by the Jewish Fraction of the Polish Communist Party, first the PPR and later the PZPR. It had around 4,000 members in 1946, and their number increased later to 7,000. Many were Jewish industry workers in Lower Silesia. The Fraction's most outspoken leaders were Szymon Zachariasz, Ber Mark and Hersz Smolar. The Fraction was an integral part of the PZPR, as well as of the CCPJ, where the Fraction's leadership had to come to terms with the Zionists. Whereas in the CCPJ and in local Jewish Committees the Fraction exerted a considerable influence, it was not popular with the Jewish population at large. Fraction activists were torn between their inherent belief that the best future for Polish Jews was in Communist Poland, and the practical considerations and policies of the Polish authorities, which supported massive Jewish emigration. ${ }^{14}$

Jewish culture in postwar Poland, in spite of the fact that most of the Jews were on the move, and in spite of the relative instability of life, was lively and impressive. It seemed that the years of suffering, death and exile resulted in an insatiable drive for those aspects of normal life that had been lost in the war. Participation in cultural and entertainment events also let those who had lost their families and friends fill a need "to be together." Although a few Jewish theatrical and entertainment performances already took place during the first months after liberation, Jewish cultural activities picked up steam only when the Jewish returnees from the Soviet Union began to settle in the large cities. Lodz and Wroclaw became major centers of Jewish theater. One of the first public Jewish events took place in liberated Lublin, as early as October 1944. It was a concert of Yiddish songs and recitations by Diana Blumenfeld and Jonas Turkow. A viewer reported: "The hall was bursting at the seams. Diana, with swollen legs, wearing a purple-red dressing gown, started to sing a song in Yiddish. She had hardly uttered the first words, when sobbing was heard all over 
the place." The first light music teams started performing in Lodz and in Lower Silesia at the end of 1945.

A full-fledged Yiddish theater began to hold performances in Lodz in the summer of 1945. Shalom Aleichem's Tevye the Milkman and Jacob Zonshein's Hershele from Ostropole were performed in the fall of that year. Ida Kaminska, the first lady of the Yiddish theater, and her husband, the actor Marian Melman, returned from Russia in late December 1946. Their first performances were in the Lodz Jewish Theater, in mid-January 1947. According to a review, "The Jews of Lodz hurried to meet with the adored artistic couple. The narrow hall of the temporary Jewish Theater on 2 Jaracza Street could hardly contain all the admirers of Kaminska's talent." The Jewish Theater of Lower Silesia, in Wroclaw, premiered in November 1947 with Gordin's “Mirele Efros”. Ida Kaminska directed it and played the leading role. This would be her most famous performance of the postwar years. She was appointed artistic director of the Jewish Theater in Lodz in the summer of 1948. Both the Lodz and the Wroclaw Jewish theaters went on tours all over Poland. ${ }^{15}$ Besides the two official Jewish theaters, Jewish cultural clubs, libraries, drama workshops and choirs existed in all major centers of Jewish population. Moreover, lectures on a wide range of Jewish-related themes, as well as Jewish poetry and prose readings, were quite frequent. ${ }^{16}$

Although a far cry from the massive and multifaceted prewar Jewish press, the postwar Jewish press in Poland was quite lively. More than seventy Jewish newspapers and journals in Polish, Yiddish and Hebrew, were published in the years 1944-1950. Among the most popular were Dos Naje Lebn (New Life), published by the CCPJ, Hashomer Hatzair's Mosty (Bridges), and Ichud's Opinia (Opinion). The mouthpiece of Yiddish writers and poets was the monthly Yiddishe Schriftn (Jewish Writings). Zydowska Agencja Prasowa, the Jewish Press Agency, run by the CCPJ, served as a significant source of information on Jews and Jewish-related themes both inside and outside of Poland. ${ }^{17}$

Historical documentation of the Holocaust began even before the war had ended. A Jewish Historical Commission was founded in liberated Lublin as early as August 1944. It moved to Lodz in March 1945. The Commission collected various sources and documents concerning the extermination of Jews under Nazi rule. A major activity, from its very inception, was the collection of personal testimonies. Among the initiators and most active members of the Commission were such Polish Jewish historians as Philip Friedman, Isaiah Trunk and Joseph Kermisz. The Holocaust was commemorated by the remnants of Polish Jewry in various ways. The high point was the annual commemoration of the Warsaw 
Ghetto Uprising on the site of the ruined Ghetto. The first gathering took place on April 19, 1945, the second anniversary of the Uprising. A monument to commemorate the Warsaw Ghetto fighters, as well as the martyred Jews of Warsaw, was unveiled on the fifth anniversary of the Uprising, in April 1948. The ceremonies were attended by thousands of Polish Jews, representatives of Polish Jewish organizations and youth movements, as well as by Jewish guests from abroad. ${ }^{18}$

The CCPJ and other organizations which assisted Jews in postwar Poland were concerned particularly about the young. Jewish children had suffered different fates during the war. Most of those who survived the war did so either with their families or as orphans and half-orphans in the Soviet Union. Others emerged from their hiding places, and still others were saved by Polish families or in convents. All in all, less than 30,000 Jewish children out of close to a million in prewar Poland survived the war. Only 5,000 children survived in German-occupied Polish lands. Although both children survivors in Poland and returnee children from the Soviet Union suffered during the war, there were differences between them. There were more orphans among the survivors than among the returnees. There were more boys than girls among the returnees. More of the youngest children, those born during the war, were returnees. As a quite large percentage of the survivor children were orphans or had only one parent, and as the economic situation was difficult, there was an urgent need for orphanages, or as they were usually referred to, "Children's Homes." The first Jewish Children's Home was established in liberated Lublin in 1944. Additional Homes were organized by the CCPJ in the spring and summer of 1945 in Lodz, Warsaw and in other centers of Jewish population. Close to a thousand children survivors lived in such Homes in the fall of 1945 . By the second half of 1946, thirteen Children's Homes existed all over the country. The CCPJ also supported needy children living with their families or in other frameworks. More than 20,000 Jewish children were aided by the CCJP in mid-1946. ${ }^{19}$

A considerable number of those Jewish children who had passed the war under assumed identities, either with Polish families or in convents, were reclaimed by Jewish organizations. Most active in what was considered then to be a "rescue operation" was the Coordination Committee, consisting of representatives of various Zionist parties. Another "rescue campaign" sponsored by Jewish religious organizations was headed by Isaiah Druker. Druker, a man in his early thirties at the time, and a captain in the Polish Army, ran a highly sucessful rescue effort almost single-handedly ${ }^{20}$

Some Jewish children studied in Polish schools; others attended 
Jewish institutions. Jewish education in postwar Poland had two sectors: schools run by the CCJP, oriented toward Jewish life in Poland, in which the official language of instruction was Yiddish, and Zionist-oriented schools run by the Hehalutz Pioneer Center, with emphasis on Hebrew and Palestine. These were elementary schools in the main. The first Yiddish and Hebrew schools were established as early as 1945 in Warsaw, Lodz, Krakow, and in a few other cities. A real boost occurred only in 1946, when large numbers of Jewish returnees from the Soviet Union arrived in Poland. Twenty-four Jewish schools, most of them in Lower Silesia, were in existence in mid-1946. Their number was almost doubled in 1947. Close to 3,000 children attended Yiddish schools, 2,000 attended Hebrew schools and more than 1,000 studied in Jewish religious schools. The number of Jewish children ages 7-14 in the school year 1947/1948, has been estimated to be 6,000. Two-thirds attended Jewish schools, and onethird Polish ones. The number of Jewish schools decreased to 33 in 1948.

A major problem in postwar Jewish schools, both Yiddish- or Hebrew-oriented, was language. Most of those children who survived in Poland, especially the youngest, spoke Polish only. Most of those who arrived from Russia spoke primarily Russian. Many of the pupils, whether in a Yiddish or a Hebrew school, had to be taught Yiddish and Hebrew from scratch. According to Dr. Samuel Amarant, head of the Hehalutz Education Department: "The incoming student body was of a highly diversified nature. There were serious problems of communication with children who spoke different languages (Polish, Russian, Ukrainian, Yiddish)." Textbooks and other instructional materials were in short supply. The constant arrival and departure of both students and teachers had a negative impact on stability and normalization. At the same time, however, an atmosphere of closeness and care usually prevailed among the educators and their pupils. ${ }^{21}$

Despite, and perhaps at least partly because of, the relatively positive official attitudes to the Jewish minority, anti-Semitism was quite prevalent in postwar Poland. Its roots were both historical and recent. To traditional anti-Jewish attitudes, fed by religion, economics and nationalism, new elements were added as a result of the war, the Soviet and German occupations and the postwar Communist regime. A central element was the stereotype of the Zydokomuna, Judeocommunism, Jewish loyalty to and collaboration with Soviet Russia. Jews were also perceived as a threat by their Polish neighbors, who had appropriated Jewish property during the Holocaust. There were also elements of a psycho-social nature, such as hate stemming from guilt in collaboration in the Nazi extermination of the Jews. Despite the enormous Jewish losses, there was hardly any 
empathy and compassion toward Jews. They were often perceived as a "threatening other." 22

Anti-Semitism in postwar Poland ranged from derogatory and offending remarks in public spaces, through physical assaults, and up to full-scale pogroms. Anti-Jewish pogroms occurred in a number of cities. Jews were also taken off trains and killed in nearby fields. Estimates of the overall number of Jews killed in Poland in the immediate postwar years vary significantly. The lowest estimate is 400 , the highest -1500 . According to a calculation based on official Polish reports, more than 300 Jews were killed between September 1944 and September 1946. A third of them were murdered in the Kielce Province alone. Certain regions and cities were more dangerous for Jews than others. Thus, according to a report by the Polish Ministry of Public Administration, close to 200 Jews were killed between March and August of 1945, nearly half of them in the Kielce and Lublin Provinces. Only nine Jews were murdered during that period in the Lodz Province. Most of the violent and deadly acts against Jews occurred between March and August 1945, and between February and July 1946. The killings decreased considerably after the summer of $1946 .^{23}$

The apogee of anti-Semitism in postwar Poland was the Kielce pogrom. It resulted in 41 killed and dozens of wounded. The Kielce events in early July of 1946, and their emotional and symbolic impact, were a watershed for Polish Jews. Many of those who still contemplated the possibility of resuming their lives in Poland decided to leave. The sense of collective security among the Jews was severely undermined. The pogrom had its repercussions within Polish society as well. Officially organized meetings in factories and offices condemned the killings and justified the punishment of the perpetrators. However, there were also incidents of popular protest against the verdicts. Among the Jewish reactions to the Kielce pogrom was a countrywide organization of self-defense, mainly in the form of local Defense Commissions, affiliated with and supervised by the CCPJ. A central Special Commission was set up in Warsaw. It supervised a network of local Special Commissions. The central and local Special Commissions maintained ongoing contacts with the regular and secret police. The Jewish self-defense network succeeded in securing some 2,000 weapons. Its people guarded close to 400 Jewish institutions throughout the country. According to a report by the Central Special Commission, it intervened with the authorities in excess of 2,000 instances related to antiJewish activities between July 1946 and May 1947..24

When Lodz was liberated on January 19, 1945, close to a thousand young Jewish survivors, whom the Germans had kept alive for cleanup 
operations, were in the area of the former ghetto. Other survivors started arriving from camps and hiding places. By the end of February 1945, more than 5,000 Jews were already living in Lodz. The first post-liberation Jewish public event occurred on February $11^{\text {th }}$. A thousand Jews participated in a mass meeting in the Stylowy cinema hall. It was chaired by the historian Philip Friedman, a representative of the Central Committee of Polish Jews, established a few months earlier in Lublin. The participants elected a local committee for Jewish affairs, which would shortly become affiliated with the CCPJ. It was headed by Michal Mirski, a veteran Communist, who had arrived in Poland from the Soviet Union with the Polish Army. The Jewish Committee in Lodz was the only Jewish committee in Poland elected by a mass meeting. The membership of other local committees was usually agreed upon by Jewish parties and organizations. The Lodz Committee's Deputy Chairman was Bernard Weiskopf, a lawyer, whose brother, Dr. Daniel Weiskopf, was admired by surviving Lodz Jews for resisting and for wounding Hans Biebow, the chief German administrator of the Lodz Ghetto. The Committee's secretary was also a lawyer, Anatol Wertheim, a communist. Among the initial members of the Lodz Jewish Committee was Feigele Peltel, better known as Vladka Meed, who had acted as liaison for the Warsaw Ghetto underground. She represented the Left Poalei Zion. Another member was Hilary Sztrowajs, a well-to-do Lodz Jew.

The most urgent task of the newly-established Committee was to assist Jews arriving daily in the city. One of its first achievements was the designation by Kazimierz Mijal, the Government representative in Lodz who shortly became its first postwar Mayor, of a thousand apartments for the incoming Jews. Mijal agreed that the Jewish Committee would directly assign those apartments, which could accommodate up to 10,000 people. Thus, Jews who arrived in Lodz during the first months after liberation faced no difficulties in getting settled there. In time it became increasingly difficult for incoming Jews to find dwelling quarters. Numerous individual Jews and Jewish families would move into apartments vacated by Jews who left the city on their way out of Poland.

A Passover Seder was held by the Committee for Jewish soldiers and officers in Tivoli Hall, on March 28. The ritual part was performed by Rabbi Szczekacz and by the head of the Lodz Jewish religious community, Josef Atlas. Among the speakers were Mirski and Wertheim. Stalin and Bierut were toasted enthusiastically. The first Jewish public cultural event in postwar Lodz, a commemoration of the anniversary of I.L. Peretz's death, was held in the Baltyk cinema hall on March 30. ${ }^{25}$

From its very inception the Committee registered all newcomers and assisted them in their attempts to find surviving relatives. Usually, the first 
place newcomers used to visit, after arriving at the railroad station, was the Committee's offices. One of those incoming Jews was Sara Zyskind, who had resided with her family in prewar Lodz. She was returning from a camp in Germany. "We had to change trains three times in order to get to Lodz, and each train was more crowded than the last. On one leg of our journey we were forced to ride on the train's roof. Early in the morning after our arrival in Lodz, my friends and I were waiting in the courtyard of the Relief Committee office. When a new group of returnees arrived from the train station, we rushed forward to scan their faces. This became our daily routine."

Mirski recalled that "the walls leading to the Committee's Registration Department were covered with hundreds of notes in all languages, mainly in Polish and Yiddish. People were looking for relatives. It was like a map of cities and towns with thousands of names." The first Jewish-Yiddish newpaper in postwar Poland, Dos Naje Lebn, New Life, which started publication in April 1945, carried pages of announcements by survivors looking for relatives, as well as announcements of Jews abroad, mostly in the US, searching for surviving relatives. ${ }^{26}$

It is difficult to establish an accurate demographic profile of the Jewish population in postwar Lodz. Many of those who arrived in the city would leave within weeks or months. Others stayed for years. The fluctuation was enormous. Still, some reliable estimates are available. The Jewish population in postwar Lodz was steadily increasing. By July 1945, more than 20,000 Jews had settled there. The number of Jews in Lodz reached 30,000 by the end of the year. At that point in time they constituted 5-6\% of the total city population and $40 \%$ of the Jewish population in Poland. There were 41,474 Jews registered in the city and province of Lodz at the end of 1945; every second person was a camp survivor. About 10,000 were returnees from the Soviet Union. Close to 7,000 survived on the Aryan side, and the rest were partisans, soldiers, and those who survived in forests and bunkers. The time of the largest concentration of Jews residing in Lodz and in the Lodz Province was apparently in late June 1946, on the eve of the Kielce pogrom. ${ }^{27}$

During the first months after liberation, an overwhelming majority of Jews residing in Lodz were people who survived under German occupation. However, the proportion of those who survived in the Soviet Union increased steadily. Whereas in early 1946, out of about 40,000 Jews who lived in Lodz, less than 12,000 were returnees from the Soviet Union, in mid-1946, out of a total of about 57,000 Jews living in Lodz and in the Lodz Province, more than 26,000 were returnees. By the end of the year more than 30,000 returnees had passed through or remained 
in Lodz. According to Mirski "the number of returnees was so large that all Srodmiejska street leading to the Committee would be packed with people. Some of them were sitting on the sidewalks. Those who could not find a room would be set up temporarily in a huge empty factory hall on Jakuba Street, in the former Ghetto area. Dom Repatrianta, the Repatriates' House on 16 Jakuba Street, was turned, eventually, into a quite comfortable place with a capacity for 700 people." 28

How many of those who settled in postwar Lodz were original Lodzer Yidn - Lodz Jews? Only a few thousand of the Lodz Ghetto Jews survived the camps and the death marches. Some of them never returned to their native city, and eventually settled in Israel and in other countries. Thousands of Lodz Jews returned from the Soviet Union and settled, at least for some time, in Lodz, while other Lodz natives settled in other cities. In mid-1947, more than 4,000 prewar Lodz Jews resided in Lodz, whereas 2,000 prewar Lodz Jews lived in Lower Silesia. It seems that a larger proportion of Lodz Jews returned to Lodz than that of Warsaw Jews who returned to Warsaw. The predominant reason was the fact that Lodz remained quite intact, while most of Warsaw was in shambles. On the whole, those few who survived tended, at least initially, to return to their prewar places of residence. There were indications that the Polish government preferred not to turn postwar Warsaw into a significant center of Jewish population. ${ }^{29}$

The age structure of the Jewish population in postwar Lodz was severely affected by the war and the Holocaust. The number of children and the old was disproportionately small. During the first months after liberation $85 \%$ of the Jewish population in Lodz were people aged 15 to 45 . Only $3 \%$ were children under age $7,4 \%$ were children aged $7-14$, and less than $8 \%$ were people older than 45 . However, as a result of the arrival of Jewish returnees from the Soviet Union, among whom there was a considerable number of families, the number of Jewish children increased. In mid-1945 less than a thousand Jewish children resided in Lodz. By January 1946 there were already more than 2,000 children, and by June 1946 - more than 4,500. In spite of the difficult conditions and the unsettled, temporary nature of Jewish life in Poland, babies were being born to Jewish families. In only one year, 500 newborns were delivered in the Jewish Hospital in Lodz, which opened in January 1947. The gender composition of the Jewish population reflected the impact of the War and the Holocaust. Thus, among Jews who settled in Lodz throughout 1945, $55 \%$ were male and only $45 \%$ were female. There was a great majority of singles. They accounted for nearly $62 \%$ of those registered by the Lodz Jewish Committee in $1945 .^{30}$ 
The significance of Lodz as a Jewish urban center in postwar Poland stemmed not only from the size of its Jewish population at a given point in time, but also from the cumulative number of Jews who had lived there for varying periods of time. Around 63,000 Jews were registered by the Lodz Jewish Committee between February 1945 and February 1947. Since the overall number of Jews who lived in Poland in the early postwar years is estimated at slightly more than 270,000 , it seems that every fourth Jew lived at least for some time in Lodz. ${ }^{31}$

Structural changes in Poland's postwar economy, the wartime uprootedness of Jewish survivors both under German occupation and inside the Soviet Union, as well as the temporary nature of Jewish settlement in postwar Lodz, affected the ways in which Jews earned a living. During the first post-liberation year, more than $40 \%$ of the Jews residing in Lodz had no profession. Among the approximately 11,500 working-age Jews in mid-1947, close to 4,500 were unemployed. Out of the 7,000 who worked, about one thousand were employed in textile factories, 700 worked in craftsmens' cooperatives, close to 1,200 were independent craftsmen, close to 1,000 worked in various administrative positions, and slightly less than 500 were petty merchants. There were also a few hundred in the free professions, mostly in medicine. The occupational profile of the Jewish population in postwar Lodz makes it sufficiently clear why many among them needed assistance from the CCPJ and other Jewish institutions. $^{32}$

Jewish cooperatives in Lodz were initiated within a few months after liberation. In mid-1946, 18 Jewish cooperatives employed more than 500 craftsmen, such as tailors, shoemakers, carpenters, metal workers and printers. An American Jewish journalist visited a carpenters' cooperative on Jaracza Street at that time. "Twenty-one carpenters were employed there. Only two were from Lodz. Almost all of them were the only survivors of their families; some had been repatriated from Soviet Russia, and some had their death camp numbers tatooed on their wrists." The membership turnover in that cooperative reflected the fluidity of the Jewish population at large. "In the course of the last two months the membership had changed several times. The founders had gone away long ago.” Still, the number of Jewish cooperatives in Lodz and their membership kept growing. Twentyone Jewish cooperatives, eight of them tailors' cooperatives, existed at the end of 1947. Twenty-eight Jewish cooperatives, with 1600 workers, were active in Lodz in $1948 .{ }^{33}$

Most of the Jews who lived in postwar Lodz resided in the midtown area. Jewish institutions and organizations were concentrated in the center of the city as well. In a sense, this was a markedly Jewish urban space, 
within the much larger and outlying space of Polish Lodz. Whereas Polish Lodz was mostly proletarian and stable, Jewish Lodz was economically and socially diversified and extremely fluid. The parameters of postwar Jewish Lodz were, approximately: Plac Wolnosci, Liberty Square, in the north, Narutowicza Street in the south, Gdanska Street in the west and Kilinskiego Street in the east. The offices of the Jewish Committee, the hub of postwar Jewish Lodz, were located on 32 Srodmiejska Street and occupied three floors. TOZ, the Jewish Health Care Society, was at number 31. Offices of Hashomer Hatzair and its Polish language periodical Mosty were at number 4, and a kindergarten run by the Jewish Committee was at number 10. Another "Jewish" street was Zachodnia, which ran parallel to Piotrkowska. The Jewish religious community center was located on 66 Zachodnia Street. The offices of the Poalei Zion party were at number 26, and some quite strange neighbors, such as the Zionist Ichud party and the PPR Section of the Jewish Committee, were at number 20. A craftsmen's cooperative run by the Bund, was at number 42 .

A short section of Jaracza Street hosted a variety of Jewish institutions. The Lodz Jewish Theater was at number 2. The Bund cultural center and a Bund craftsmen's cooperative were in the same building. Poalei Zion and its youth movement Dror were located at number 4 . The offices of the Poalei Zion-Left party were at number 15, and of the Bund at number 17. Hashomer Hatzair activities in postwar Lodz were held at 49 Kilinskiego Street. Several rooms were used by the youth movement and by a cultural center. Close by was also the editorial office of Hashomer Hatzair's publication, Mishmar. The Jewish-Yiddish school named after the writer I.L. Peretz, run by the Lodz Jewish Committee, was also located at 49 Kilinskiego Street.

Narutowicza was one of the most modern and impressive streets in the center of Lodz. Number 32, a huge, stylish and elegant building, planned by the Jewish architect Gustaw Landau-Gutenteger was built before the First World War. After the Second World War it hosted the Society of Jewish Writers, Journalists and Artists. Here too were the editorial offices of Dos Naje Lebn. Some of the Jewish writers and journalists, such as David Sfard, Joseph Kermisz, Nachman Blumental and Rachel Auerbach lived in that building. Inside its extensive inner yard were located the CCPJ storage rooms, full of used clothing donated to the Jews of Lodz by American-Jewish organizations. ${ }^{34}$

Lodz was the center of Jewish culture in Poland during the first postwar years. According to Hersz Smolar, one of the communist Jewish leaders, "Lodz became a drawing magnet for the Jewish intelligentsia." The most significant Jewish cultural institutions and organizations, such as 
the Association of Jewish Writers, Journalists and Artists, and the Central Jewish Historical Commission, were located in this city. The first postwar Jewish newspaper started publication in Lodz. Jewish scholars, writers, and artists settled, at least for a while, in Lodz. Among them were the historians Philip Friedman, Bernard Mark and Joseph Kermisz, the writers Chaim Grade, Binem Heller, Isaac Ianasovich, Shmerke Kaczerginski, Mendel Mann and Joseph Rubinstein, the poets Nachum Bomze, Abraham Sutskever and Rachel Korn, the journalist Leon Leneman, the composer Shaul Berezovski, and the filmmaker Natan Gross. A number of landsmannschaftn, Jewish hometown associations, were founded in postwar Lodz. The largest and most active was apparently that of Vilna Jews. ${ }^{35}$

Postwar Lodz was home to a wide range of Jewish periodical publications in Yiddish, Hebrew and Polish, representing various and at times conflicting views and opinions. The first Yiddish typesetting fonts found in Lodz after liberation were unearthed among the ruins of the former ghetto in February 1945. They had previously been used for the printing of the ghetto newspaper. The first issue of Dos Naje Lebn was published in Lodz, on April 10. It became the official publication of the CCPJ for the next five years. As early as 1945, its circulation reached 7,000 copies. Its chief editor was Michal Mirski. Initially, the editorial board represented all major ideological and political trends within postwar Polish Jewry. In time, it became the mouthpiece of the Jewish Communists. A Yiddish publishing house, bearing the same name and headed by Mirski, was also established. By early 1947, it had a staff of sixty-three. Besides salaries, paid by the Jewish Committee, the employees received material assistance from time to time. According to a list dated January 1, 1946, the writer and journalist Rachel Auerbach received a dress, a skirt, a blouse, a sweater, a dressing gown and a pair of shoes. Aleksander and Tosia Klugman, a typesetter and his wife, received 12 items each. Chief Editor Mirski got on that occasion a waterproof coat and three pairs of socks. ${ }^{36}$

Jewish cultural events became a common feature in Lodz quite soon after liberation. Here is a sample of events which took place between midMay and early July 1945:

Rachel Auerbach read excerpts from her wartime writings at the Committee of Jewish Writers, Journalists and Artists, on May 18.

The singers Diana Blumenfeld and Dido Epstein performed at the Sala Spiewakow, The Singers' Hall, on May 19th and 20th.

There was a commemoration of Shalom Aleichem at the Sala Spiewakow on June 3.

The popular prewar Yiddish film Mayn Shtetl Belz (My Town of 
Belz) was screened in Wlokniarz, the largest cinema hall in town, on June 16 .

Dr. Adolf Berman, the leading leftist-Zionist politician, spoke at the Baltyk cinema hall on June 17, and Chayele Rozental, a young Jewish singer and survivor of the Vilna Ghetto, performed on that day.

A commemoration of Herzl and Bialik took place at the newly opened Hehalutz House on July 2.

A Zionist celebration, with the participation of the hero of the Warsaw Ghetto uprising, Antek Zuckerman, was held on July 8.

Literary evenings with the participation of new arrivals from the Soviet Union drew Jewish literary-minded audiences. One of the first events of this kind was a reception in honor of Bernard Mark, Moshe Grosman, Nachum Bomze, Mendel Mann and Shmerke Kaczerginski in early March 1946. A literary evening dedicated to Soviet Yiddish literature with the participation of close to twenty speakers took place on November $8,1947 .^{37}$

Polish people, mostly leftist intellectuals and writers, participated in some of the Jewish events. A poetry evening dedicated to Wladyslaw Broniewski, a leading "proletarian" Polish poet who had lived for some part of the war in Jerusalem, was held at the Hashomer Hatzair Cultural Center in early November of 1946 . The evening opened with greetings by Binyamin Tene-Tenenbaum, Broniewski's Hebrew translator. Broniewski read some of his Jewish-oriented poetry, such as the poem "The Western Wall." He was most known in the Jewish intellectual circles for his elegiac poem "For Polish Jews." Broniewski told the public about life in the kibbutzim, in Palestine. He also strongly condemned anti-Semitism in postwar Poland: "As a Pole I am ashamed that even today, after the murder of millions of Jews, there is still anti-Semitism in Poland." Leszek Kolakowski, at that time a young philosophy student at Lodz University, recalled participating in an event celebrating the unification of the socialist Zionist youth movements Borochov Yugnt and Dror. There was also a continuous flow of visitors from abroad, mainly from the US and Palestine. Yitshak Gruenbaum, a prominent Zionist leader in prewar Poland who had settled in Palestine, spoke at the Wlokniarz cinema hall. His popularity was such that people bought tickets to the film screened before his speech, so as to secure seats. Another famous visitor was the popular Soviet-Jewish writer and journalist Ilya Ehrenburg. He visited Lodz in the fall of 1947 and spoke to an overflowing Jewish crowd. At a reception hosted by the Organization of Jewish Writers and Journalists, Ehrenburg spoke of the 
wartime Jewish tragedy and of contemporary anti-Semitism, but he also criticized Jewish generalizations and stereotypes concerning anti-Semites and anti-Semitism. ${ }^{38}$

It was only natural that the commemoration of the Holocaust would be a recurring theme in public Jewish events. The first Jewish commemorative event in postwar Lodz took place on November 1, 1945; it was announced officially as a commemoration day for the victims of Nazi Germany in Poland. According to a report by the Jewish Press Agency, "a mass march, including representatives of the Polish community, all Jewish political and social organizations, and Jewish schoolchildren started at the Lodz Jewish Committee offices on Srodmiejska Street. An Army Honor Guard was waiting for the marchers at the Jewish cemetery." Among those who spoke on that solemn occasion were head of the Lodz Jewish Committee Michal Mirski, and the head of the Jewish congregation, Rabbi Krawiec. Another occasion was the annual memorial for the Lodz Ghetto victims. The Jewish Telegraphic Agency reported that "on September 27, 1947, the Jewish and Polish community of Lodz marked the third anniversary of the liquidation of the Lodz Ghetto." A ceremony to unveil a commemorative plaque took place at the Jewish cemetery. Numerous delegations laid wreaths at the martyrs' tombs. In September 1949, the commemoration ceremony at the cemetery was attended by 2,000 people. ${ }^{39}$

Another highly-attended event was the anniversary of the Warsaw Ghetto Uprising. The fourth anniversary, in April 1947, was celebrated in Lodz at the Polish Army Theater. The first speaker was Mirski. Marek Edelman and Tuvia Borzykowski, both participants in the Warsaw Ghetto Uprising, shared their memories with the audience. The renowned Jewish actress, Ida Kaminska, was one of the performing artists. A fundraising campaign for the erection of a monument to commemorate the Warsaw Ghetto Fighters was initiated in the early fall of 1947. It was widely supported by all Jewish organizations in Lodz. Impressive donations were raised by local Jewish cooperatives. ${ }^{40}$

Postwar Lodz witnessed at least two trials against Nazi perpetrators, that of Rudolf Krampf and that of Hans Biebow. Krampf, a Volksdeutsche, worked in Lodz as a printer before the war. After the establishment of the Lodz Ghetto he became one of the chief assistants to Biebow, the Ghetto Administration chief. He was also involved in the organization and functioning of the Chelmno death camp, not far from Lodz. Numerous witnesses appeared in the course of Krampf's trial in December 1945. Among them was fifteen-year-old Shimon Srebnik, whose testimony would open Lantzman's monumental film Shoah, decades later. Srebnik told the court how he, together with other Jewish teenagers, had been forced to 
burn bodies of gassed Jews. When the Red Army advanced in the direction of Chelmno and Lodz, in January 1945, Krampf ordered the shooting of these youngsters. Srebnik, though severely wounded, managed to survive. Krampf also planned to kill the last of the young ghetto Jews, who were supposed to clean the area after the final deportations to Auschwitz. He was sentenced to death. ${ }^{41}$

The trial of Hans Biebow, "the butcher of the Lodz Ghetto," was held in late April 1947. Biebow, a middle-class German merchant born in Bremen who had joined the Nazi Party, was nominated to be head of the Lodz Ghetto administration. He was not only responsible for implementing Nazi policies in respect to the ghetto Jews, but was personally involved in torture, rape and killings. He often used his official position to seize Jewish property and valuables. Biebow traveled from Lodz to Dresden in connection with his business activities, in mid-January 1945, a few days before the arrival of the Red Army. He was identified and picked up by the British, on a request of the Polish legal authorities.

It was the trial of Krampf that led to the identification of Biebow in Germany. He was extradited to Poland in May 1946 and brought to the Sterling Street Prison in Lodz at the end of June. Biebow's trial started in the morning of April 23, 1947, in the Lodz District Court on Dabrowski Square. It provoked wide public interest,and was reported on daily by the general Polish press, as well as by local Lodz newspapers. Numerous Jewish witnesses gave evidence in the trial. Historian Arthur Eisenbach quoted from the extensive documentation collected by the Jewish Historical Commission. Mirski, head of the Lodz Jewish Committee and Chief Editor of Dos Naje Lebn, was one of the three aldermen appointed by the court. Dos Naje Lebn reported that "a huge Jewish crowd assembled on Wednesday, April 30, inside the courtroom and in front of the loudspeakers installed in the street, to hear the verdict." The final court session was covered by Polish and foreign media. Biebow was found guilty and sentenced to death. His appeal to President Bierut was rejected. He was hanged at dawn, on June $23 .{ }^{42}$

One of the most remarkable achievements of postwar Jewish culture in Poland was the Jewish Theater of Lodz. Most of its actors and staff were returnees from the Soviet Union, who had begun to arrive in Lodz in the spring of 1946 . The Theater's opening was officially announced in August. Its first director was Moshe Lipman, who had just returned from Russia with his wife, the actress Natalia Lipman. Among the other artists were Aizik Rotman, Nadia Kareni, Eni Liton and Ketty Efron. They were joined by a few graduates of Mikhoels' Yiddish State Theater Studio in Moscow. Between August and December 1946 the Theater performed 
eight plays. In January 1947, it premiered with Anski's classical Yiddish play, "The Dibbuk." Altogether eleven productions were staged in the course of the year. They included mainly classical and popular Yiddish plays by such writers and playwrights as Shalom Aleichem, Goldfaden and Gordin. Ticket statistics indicate how popular the Lodz Jewish Theater was. More than 28,000 tickets were sold throughout 1947. In 1948 the Lodz Jewish Theater went on tour in Poland and abroad. ${ }^{43}$

By mid-1948, the renowned Yiddish actress Ida Kaminska, daughter of Ester-Rokhl Kaminska, "the mother of Yiddish theater," had become the art director of the Lodz Jewish Theater. She was assisted in administrative and organizational matters by her husband, the actor Marian Melman. Kaminska was not only an excellent actress, but also a resourceful and energetic director. With the help of Jack Greenbaum of New York and the assistance of the CCPJ, Kaminska renovated the small and modest hall on 2 Jaracza Street. One of the first plays performed in the renovated theater was Kaminska's adaptation of Max Bauman's Glueckel Hameln Demands Justice, with Kaminska in the leading role. The gala premiere in November 1948 was attended by the Polish Minister of Culture, the Mayor of Lodz and CCPJ representatives. Leon Schiller, Poland's leading theater director, sent a congratulatory telegram. He had always been an enthusiastic supporter of the Jewish theater in Poland. Kaminska made continuous efforts to get official approval and financial support for the construction of a large modern Jewish theater building in Lodz. ${ }^{44}$

The most popular Yiddish actors in postwar Poland, besides Ida Kaminska, were the comedians Shimon Dzigan and Israel Schumacher. Their paths crossed for the first time in Brodersohn's theater studio in prewar Lodz. Dzigan was raised in the poor Baluty neighborhood. Schumacher was from a middle class family, and he graduated from one of the best high schools in town. They started performing together in the Ararat Revue Theater, which specialized in Jewish folklore, and soon became popular with Jewish audiences. Dzigan and Schumacher were among the throngs of refugees who escaped eastward in the fall of 1939 and eventually found themselves in remote regions of the Soviet Union. They tried to join General Anders' Polish Army, but were accused of desertion and sent to Soviet labor camps. They were released only in August 1946, and shortly thereafter were rearrested. Dzigan and Schumacher managed finally to leave the Soviet Union in the summer of 1947, reaching Warsaw first and settling later in Lodz.

Dzigan and Schumacher's performances in postwar Lodz were a tremendous success. The crowd at their first program, Abi men zet zikh (We Meet Again) was huge. The reunion between the Yiddish speaking 
audience and the popular Yiddish comedians after years of suffering and loss was highly emotional. Both audience and actors stood for a few moments facing each other and cried. Dzigan and Schumacher were the highlight of the New Year's Artists' Ball at the Lodz Jewish Theater, on December 31, 1947. Musical arrangements for the Ball were by Shaul Berezovski. Among the performing actors were Sylvia Swen and Ketty Efron. The dancing went on up to the early hours of the morning. Dzigan and Schumacher's subsequent programs, such as Nu, un vos vayter? (So, What's in the Future?) and Zingendik un Tantsndik (With a Song and a Dance) were based on prewar themes, on their wartime experiences, and on hopes for the future. Dzigan and Schumacher went on extensive tours to Jewish population centers throughout Poland..$^{45}$

Modest attempts to renew Jewish filmmaking in postwar Poland were initiated in Lodz, the center of Polish film production at that time. This is where Kinor, a Jewish filmmaking cooperative, was founded in the fall of 1946 by the Goskind brothers, the leading producers of Yiddish films in prewar Poland, who had survived the war in the Soviet Union. Kinor functioned under the auspices of the CCPJ, while funding was supplied by the JDC. Facilities and technical support were provided by Film Polski. Most of Kinor's productions were newsreels and short documentaries on Jews and Jewish life in postwar Poland. The first full-length documentary, produced in 1947, was Mir Lebngeblibene (We, The Survivors) directed by Natan Gross.

The film documented various aspects of Jewish life in Poland in the immediate postwar years. It opened with el maleh rahamim, the traditional prayer for the dead, performed by cantor Koussevitski, went on to show the excavation of the Ringelblum archive from under the rubble of the Warsaw Ghetto, and presented scenes from the Lodz Jewish Committee offices, where survivors attempted to find information about their families. A considerable part of the film showed Jewish children and youth in CCPJ Children's Homes and in various Zionist youth movements. Its last part portrayed Jewish culture and entertainment. The film was warmly accepted by Jewish audiences throughout Poland, but its screening for the general Polish public was not allowed. A shorter documentary was filmed in the spring of 1948, documenting the fifth anniversary of the Warsaw Ghetto Uprising. Still another, apparently the last one prepared by Kinor in postwar Poland, was a film about the arrival of the Israeli Legation in Warsaw. Polish-Israeli relations began to deteriorate quite soon, as a result of the Cold War. The film was never screened in Poland. It was smuggled to Israel illegally. ${ }^{46}$

Undzere Kinder (Our Children) was the only full-length Jewish 
feature film produced by Kinor in postwar Poland. The movie's ideas and concepts, its implementation, as well as the film's fate, reflect the vicissitudes and hardships of Jewish/Yiddish filmmaking in Poland. The initial idea was Shaul Goskind's. He decided to make a film that would center on Dzigan and Schumacher, who had just returned from Russia. Time was of the essence: it was quite clear that the two popular comedians would not remain in Poland for long. It was only natural that the film must, in some way, present the tragedy and rebirth of Polish Jewry. Still another problem was postwar Polish politics and propaganda. These constraints resulted in the production of a rather eclectic film, in which various and at times contradicting concepts and stories were pieced together. Goskind first approached Arnold Mostowicz, a Lodz born physician, writer and editor, and survivor of the Lodz Ghetto. Mostowicz could not see how the tragedy of the Holocaust could be combined with the comedy of Dzigan and Schumacher. Finally, the scenario was worked out by a group of people - the film's director Natan Gross, the writer/historian Rachel Auerbach and the two comedians. Auerbach worked at the Jewish Historical Commission and was familiar with numerous war and survival testimonies. Gross was deeply involved in documentary filming, with special emphasis on children and youth. Dzigan and Schumacher would play themselves, Jewish actors - comedians, returning from Soviet Russia and facing the grim realities of post-Holocaust Poland.

Undzere Kinder centers on the comedians' visit to a Jewish Childrens' Home, where they perform in front of the young audience. When late in the evening they walk upstairs to their bedrooms, they peak through keyholes, and are surprised and shocked to witness "stories of survival," flashbacks into what some of the children had undergone during the war. The dramatic and depressing nighttime sequences are in a way "erased" and substituted by the next morning's sunshine and playground scene in which the children are normal again, and even make fun of the comedians. Then comes the "happy end," the departure of the actors, surrounded by marching and singing children. Decades later, when one of the performing children, a survivor from the Vilna Ghetto, was asked about the connection between his acting in the film and his factual past during the war, he remarked: “The filmmaking of Undzere Kinder was a happy time in my life and in the lives of the other child actors. This was a new and interesting experience. We did not talk about the past. We lived the present and wanted to return to a normal existence, to have fun." As far as the performers in this film are concerned, there is a mix of professional actors, such as Dzigan and Schumacher, Moshe Lipman, Nusia Gold and Nadia Kareni, and non-professional children-actors from the Helenowek 
orphanage and from the Hebrew and Yiddish schools in Lodz. The musical adaptation is by Shaul Berezovski, who used the already popular Jewish Partisans' Song for the film's main musical theme. This, along with other songs in the film, was performed by the Hebrew School children's choir, directed by Israel Glantz. ${ }^{47}$

What is the significance, if any, of Undzere Kinder? First of all, this was one of the first representations of the Holocaust in postwar cinema, and one of the earliest feature films on the subject. At the same time, however, it does not form a defined and well-thought-through entity. It is rather a montage type of creation, full of contrasts and contradictions: past and present, memories and expectations, grief and hope, tragic loss and comic distractions, adult professionals and amateur children actors. Another set of questions concerns the problem of how to confront the Holocaust: should this be done through reenactment of a traumatic past, as in the bedroom flashback stories of the orphans, or through avoidance of the past and a turn towards a hopeful future, as presented by the playing, working, marching and singing children? Then, there is also the impact and influence of social realism, Soviet-style, prevalent at the time in Russia and in its satellites. One cannot grasp the substance and fate of Undzere Kinder, without considering the political context of postwar Poland in general, and the Polish-Jewish context in particular. Even if Undzere Kinder is not an impressive achievement in the pure artistic sense, it is significant as an early presentation of the Holocaust. The film was never screened to the public at large in Poland, because of the changing political circumstances. What was, perhaps, permissible when the scenario was being written, became taboo by the time the filming and the editing were completed. ${ }^{48}$

Two Jewish elementary schools existed in postwar Lodz, the Peretz Yiddish school on 49 Kilinskiego Street and the Ghetto Fighters' Hebrew School on 18 Poludniowa Street. The Yiddish school, run by the Lodz Jewish Committee, opened in mid-September 1945 in an apartment on 15 Jaracza Street. Initially, only 45 pupils were taught there by four teachers. One of the teachers was Mendel Mann, a Yiddish writer who had survived the war in Soviet Russia and was serving as head of the Education Department of the Jewish Committee in Lodz. The number of students increased to 180 in the spring of 1946 . The school then moved to more spacious quarters, on 49 Kilinskiego Street. This was a large building with an inner court. Two floors were assigned by the Lodz municipality to the Jewish Committee for the school. The number of students soon increased to about 300, and the number of teachers to twelve. At the end of 1946 the number of students in the Peretz school was close to 400, and the number of teachers, twenty. Its principal in the years 1945-1949 was 
Michal Helman, a member of the Left Poalei Zion. ${ }^{49}$

The Hebrew school began as a private educational institution in the fall of 1945. This was the first Hebrew school in postwar Poland, and it was run by Hehalutz, the coordinating center of Zionist youth movements. The school was initially located at 72 Wschodnia Street, but it soon moved to larger quarters at 18 Poludniowa Street. A number of former apartments in that building were turned into classrooms. Its founding principal was Baruch Kaplinski. The subsequent principals were Shaul Liberman and Aharon Rashal. More than a hundred children enrolled in the school within the first few days of its opening. The number of students reached 250 in 1946. It was one of the two largest Hebrew schools in Poland at that time. The school's name, The Ghetto Fighters' Hebrew School, was suggested to Kaplinski by Antek Zuckerman. Whereas in the Peretz Yiddish school Hebrew was just one of the subjects of instruction, it was taught intensively in all grades of the Ghetto Fighters' school. The instruction and the general atmosphere of the school were distinctly Zionist and Palestine-oriented. Hundreds of students must have passed through it. Following the emigration of Lodz's Jews to Palestine/Israel and elsewhere, the number of students shrank. By January of 1949 only 153 students attended the school, and it had only twelve teachers. ${ }^{50}$

The Helenowek Jewish Children's Home, usually referred to as Helenowek, was located on the northern outskirts of town, close to an extensive forested area. A wide alley bounded by old chestnut trees led to the main building. A Jewish orphanage run by Chaim Rumkowski, the future "King of the Lodz Ghetto," existed there prior to the war. The orphanage consisted of a number of modern buildings with heating and hot and cold water, which were not too common in prewar Lodz. There were a few small playgrounds for the younger children and a large playground for the older ones. The Helenowek Children's Home also owned a small agricultural farm and an impressive greenhouse. It opened in May 1945, under the auspices of the Lodz Jewish Committee. Maria Feingold was appointed as its director in the fall. She had extensive experience in education before the war. During the war she headed a Polish school and a Polish orphanage in Samarkand, in Soviet Uzbekistan. Among the first children placed in Helenowek by the Lodz Jewish Committee were seven boys, Lodz Ghetto survivors, originally from Germany. They didn't stay for long.

The ages and wartime experiences of the incoming inhabitants of Helenowek varied greatly. Thus, of the ninety children and teenagers who lived in Helenowek in the fall of 1946, twenty-nine were aged 2-6, twenty were aged 7-9 and forty-one were aged 10-18. As for where and how they had survived the war, more than half were returnees from the Soviet 
Union, twenty-five survived as Aryans, nine came from camps, seven survived in convents, and two were children-partisans. Most of the schoolage children in Helenowek attended the Peretz Yiddish school. ${ }^{51}$

Although the average number of children in Helenowek in the subsequent years fluctuated around one hundred, there was a steady outflow and inflow of residents. Thus, in January 1947, ten children left and twelve arrived. However, in March of that year only six left and twenty-two arrived. Among them were Herszek Grynberg, the future Polish-Jewish writer, and Chaim Preter, one of the children-actors in Undzere Kinder. Only a minority were orphans. Most of them were either half-orphans or children with parents who for various reasons had sent them to Helenowek. Out of ninety-eight inhabitants in November 1947, twenty-four were orphans, forty-five had one parent and twenty-nine had both parents. Difficult economic and socio-psychological conditions forced some parents to separate from their children.

Many of the Helenowek children arrived undernourished and sick. Some had serious emotional problems. A psychologist who tested a number of children in Helenowek in early 1946 reported that "Alex, though quite intelligent, is extremely timid, and Stanislaw suffers from rage attacks." Some of the youngest children couldn't talk properly and others suffered from mental disorders. Some were illiterate. The majority, though, improved in time, both physically and mentally. Most of them were successful in school. ${ }^{52}$

Feingold's concept of running the Helenowek Children's Home was to delegate responsibility to its residents and endow them with pride in their achievements. A Children's Council was elected from time to time, and the Helenowek Chronicle documented everyday life in the Home. Sven Sonnenberg, one of Helenowek's graduates, remains full of praise for the Home, and particularly for its Director. "Looking back it seems that her personality carried the day. She never raised her voice or used physical discipline. Mrs. Feingold, by the force of her personality, created a unique milieu. The care was superb, the discipline and standards to strive for were demanding. Most of us, her children, kept a very close relationship with her, way into our adult lives, even in retirement and from abroad." Sven also recalled another Helenowek mentor, Ms. Maria Milstein. "Ms. Milstein was a lifelong communist. She was a tall, rather skinny spinster. She never smiled. Her life was absolutely devoted to spreading and solidifying communism. In other aspects she was reasonable and very caring about the children under her supervision." The Helenowek Children's Home became a showpiece of the Lodz Jewish Committee. Besides educational achievements in the Lodz schools, a wide range of arts was taught on the premises. Some of the 
best Jewish instructors in dance and music were active there. Among them was Sylvia Swen, an experienced dance and rhythmics teacher, Judith Berg and her husband Felek Fibich, who taught Jewish-Yiddish folk-dancing, the orchestra director Frydland, and the choir director Igor Glantz. When Undzere Kinder was filmed in 1948, Helenowek was selected as the location for many of the shots. Jewish Committee members and journalists from Dos Naje Lebn would often visit the Home. The Helenowek dance group and choir were invited to perform for representatives of various Jewish organizations from all over Poland..$^{53}$

The so-called Bursa was in fact a Jewish youth dormitory. Young Jewish men and women, mostly without families, started arriving in Lodz in the first months after liberation. These were either camp survivors or those who were hiding on "Aryan" papers during the war. Some of the newcomers had served in the Soviet and Polish armies and a few had been partisans. Growing numbers of young people kept coming with the successive waves of Jewish returnees from the Soviet Union. Although officially the Bursa was meant for both working and studying Jewish youth, a pronounced majority of its tenants intended to start higher education. Some had to complete their prewar schooling. Others, who had completed their secondary education before the war, were looking forward to higher education. The age profile of the "Bursants" varied, from the upper teens up to the late twenties. What was common to all was a prevailing urgency to start a new life after years of war, exile and loss. In those difficult times, the Bursa was an ideal place to live and study. It provided both an appropriate physical setting and a friendly, encouraging social environment. The Lodz Bursa, the first of its kind in postwar Poland, was funded by the CCPJ and opened in late March 1946 in the former ghetto area at 15 Franciszkanska Street. The opening ceremony was attended by Lodz mayor Kazimierz Mijal, Lodz Jewish Committee head Michal Mirski, and representatives of various local institutions of higher education. On the average, around 150 people resided on the Bursa premises, but since there was a considerable turnover, hundreds of young Jewish men and women lived there for varying periods of time. ${ }^{54}$

The Bursa, according to its former occupants, was much more than just a dormitory. Rachelka Kaufman wrote years later "We started to live a new life in that house on Franciszkanska 15. Living with that group of people who had survived the horrors of war, and a feeling of togetherness, strengthened us." Adam Broner recalled that "the Bursa was for us, those who survived the wartime catastrophe, a new home and family. It was there that we started a new life and formed longtime friendships." $\mathrm{He}$ recalled that the elite at the Bursa were the university students, who 
showed off their colorful academic caps. Many of those who initially worked in factories and cooperatives eventually decided to study. Among the "Bursants" were future engineers, physicians and professors. Adam Broner shared a room with Kuba Goldberg, who later became a known historian. Another roommate was Lucek Dobroszycki, who would become a leading scholar of the Holocaust and editor of The Chronicle of the $\operatorname{Lod} z$ Ghetto. People were intensively involved in their studies as well as in social and cultural events. There was a lot of singing and dancing. The Bursa even boasted its own choir, directed by Wlodek Szejnman, a future surgeon. The Bursants rarely returned to their recent past. Pola Calecka wrote years later, "It seems that each one of us, subconsciously, ran away from the nightmarish past." Henryk Fajnhaken remembered heated political discussions, particularly during the first two years of the Bursa. The gamut ran from staunch Communists through socialists and Bundists and up to outright Zionists. He recalled a rather unexpected event: "A group of dedicated Communist girls disappeared one night and went off to Palestine." Memoirs of former Bursants speak of prevailing notions of togetherness and "family." As a matter of fact, some real families started in that crowded dormitory. A few children were born and raised there. One mother recalled "the first child was born. Ours. Halinka had a mother and a father but no other family. However, quite soon she discovered that she had a lot of aunts and uncles." 55

Jews arriving in Lodz after its liberation encountered various forms of anti-Semitism. Prewar Lodz Jews who survived and returned found their homes occupied by Poles. Some of them managed to recover their apartments by legal action. Others did not. An American-Jewish journalist who visited Lodz shortly after the war found that "the most bitterly disappointed were the repatriates of Lodz who had found their homes intact but nevertheless had to move to the refugee center on Jakuba Street." Some Jewish children who attended Polish schools in postwar Lodz encountered anti-Semitism. Samuel Bak, who had survived the Holocaust in his native Vilna, and who would later become a renowned artist, recalled that he was mocked by his Polish classmates. "My classmates would come up to me, sniff me out and murmur that 'for a regular kike' I smelled not too bad. There was no attempt at physical violence, no pushing, pulling or kicking, but the overt anti-Semitism of a few boys, nonchalantly tolerated by all the others, started to annoy me greatly." He left school and went to study art with a private tutor. ${ }^{56}$

Though Lodz seemed to be safer for Jews than other cities, antiSemitic moods prevailed among parts of its population. Rumors of all sorts, quite typical of the immediate postwar years, generated anti-Jewish 
suspicions, fears and accusations. According to a rumor circulated in Lodz in the summer of 1945 , every Jew returning from the camps was receiving 30,000 zlotys. A much more ominous rumor spread in town in the spring of 1946, around the Passover Holidays. Mijal, the mayor of Lodz, speaking at the inauguration of the Bursa, mentioned a rumor about supposed kidnappings of Polish children by Jews. Still another rumor spoke of great numbers of Jews being brought in from Soviet Russia. A leaflet circulating in Lodz in the summer of 1946, warned that "the Government planned to send 60,000 Jews to Lodz, in order to take over the industry." 57

An accusation, prevalent in Lodz as well as all over Poland, was that the Polish security establishment had been permeated by Jews. As a matter of fact, some of the highest positions at the Lodz regional military court, a major instrument of repression, were occupied by Jews. Some Jews were also among the leadership of the Lodz WUPB, the Regional Office of State Security. The fact that some Jews held leading positions in the Security apparatus was widely used by the political opposition to the Communist regime in the immediate postwar years. Anti-Semitic rumors and accusations in Lodz, and in the country as a whole, should also be viewed in their specific postwar context. Poverty and lack of supplies were quite widespread. The Jewish population received material assistance from foreign Jewish organizations, and some Jews received help from their families abroad. ${ }^{58}$

Killings of Jews occurred in Lodz and in the Lodz Province. According to one report, eighteen Jews were murdered in the Lodz Province in JanuarySeptember 1945. Another report states that fifty-one Jews were murdered in the Lodz Province during the first year after liberation. The same report stated that sixty-four Jews were killed in the Lublin Province and fifty-seven in the Warsaw Province over the same period of time. The fact that there were more killings in provinces with a smaller Jewish population than in the Lodz Province indicates that it was relatively safer for Jews to live in and around Lodz than in other areas. It also seems that most of the killings took place in Lodz Province rather than in the city itself. According to Marek Edelman, a student of Medicine in postwar Lodz, a Jewish female student of Medicine was murdered while traveling from Lodz to Pabianice, where she lived. "During the first few months after liberation, trams between the city and nearby towns didn't run yet, and people traveled by trucks. Two armed Polish youngsters stopped the truck on which that medical student was traveling, ordered her to get off, and killed her on the spot."

Another murder occurred half a year after liberation. Aron Ellenblum, a lonely and sickly cigarette peddler residing on 61 Pilsudskiego Street, was killed in the morning hours of August 25, 1945. Ellenblum's wife 
and two children had perished in Auschwitz. A survivor of several camps, he returned to his native Lodz shortly after liberation. A Jewish woman residing on 101 Limanowskiego Street was killed by three members of the nationalistic underground in early November 1945. They demanded cash, and since she didn't have any, they shot her. Severely wounded and unconscious, she was brought to a hospital, where she died. Fiszl Barbanel, a barber, was murdered in early December 1945, in the Poniatowski Park. The body was found a few days later. Four members of a religious Zionist kibbutz in Lodz, three men and a woman traveling from Lodz to Krakow, were murdered on their way in early March 1946. They were apparently beaten before being shot. All were camp survivors in their early twenties. Their funeral left from the Mizrachi kibbutz location on Poludniowa Street and was attended by a huge Jewish crowd. Among those who eulogized the victims were representatives of the Lodz Jewish Committee, the Lodz congregation, and Louis Segal of the World Jewish Congress, who was visiting Poland at the time. ${ }^{59}$

The most notorious murder of a Jew in postwar Lodz was that of Feliks "Fishke" Neiman, a Bund activist. He was shot in the afternoon hours of June 24, 1946. When his Bundist friends arrived in his apartment to take him to a Party meeting, they found his bloodied body in the bathtub. The murderers took his gun and his army uniform. Before the war Neiman had been a leading member in Tsukunft, the Bund youth movement. He survived the war in the Soviet Union, and returned to Poland as an officer with Berling's Army. Besides his political activities as a Bundist, he worked as a foreman in a Jewish tailoring cooperative, and studied at Lodz University. Neiman's funeral was attended by thousands, both Jews and Poles. Among them were his fellow Bundists and numerous Jewish cooperatives workers. Representatives of the PPS, PPR and other local Polish organizations paid their tribute as well. Among those who spoke at the cemetery were representatives of the Bund Central Committee, the Polish Army and Lodz University. ${ }^{60}$

The Kielce events, in early July 1946, affected Lodz Jews as they affected Jews all over Poland. The front page of Dos Naje Lebn of July $12^{\text {th }}$, all in black, listed the names of the murdered under the headline "The Martyrs of the Kielce Pogrom." The following pages abounded in gruesome details of what had taken place in Kielce on July $4^{\text {th }}$. Antek Zuckerman, dispatched by the CCPJ, traveled to Kielce in the wake of the pogrom and discussed with local Polish officials the possibility of moving all Jews from there to Lodz. His most urgent task, though, was to immediately move the wounded victims. Zuckerman traveled with the wounded to Lodz in a special Red Cross train, guarded by an army unit. 
He recalled that there was tension in the air. "At every stop, we got out with the soldiers and surrounded the train to protect it. In the morning we arrived in Lodz, where ambulances were waiting for us." The wounded were taken to a local hospital. One of them, Simcha Sokolowski, died in the hospital. His funeral, attended by a large crowd, was organized by the Lodz Jewish Committee. Among official protests against and condemnations of the Kielce pogrom there was also a protest signed by thirty-seven Lodz writers, artists and scholars.

A number of anti-Semitic incidents in Lodz were reported in the second part of July 1946. Grafitti calling for an anti-Jewish pogrom appeared on some walls. There were also rumors about an aborted pogrom planned for mid-July, with the Helenowek Children's Home as a primary target. An incident almost did occur at the Dom Repatriantow Zydowskich, The Jewish Immigrants' House, on 16 Jakuba Street. “A crowd started gathering in front of the House, and anti-Jewish threats were voiced. The police, informed by telephone, appeared immediately, within eight minutes of the call. They arrived in dozens of trucks. The crowd was dispersed on the spot." Some hooligan incidents occurred at Plac Wolnosci. Marek Edelman was attacked on Narutowicza Street. ${ }^{61}$

The Kielce pogrom had a profound impact. Thousands of Jews who had considered settling in Poland for good, or delaying their departure, decided to leave at once. A Jew residing in Lodz described the post-Kielce moods and attitudes: "We, people who lived in the largest Jewish community, i.e. in Lodz, though we sensed that our existence was anchored in quicksand, we didn't allow this sensation to affect our consciousness. We wanted to resume living again as human beings. The Kielce pogrom woke us up from our illusion. One shouldn't stay here even for a moment." Still, Lodz respondents to a sociological survey conducted at the time among Polish Jews mentioned the Kielce pogrom less than Jews from other localities. It is possible that although the Kielce pogrom affected Lodz Jews in one way or another, they felt relatively safer than Jews living in other places. According to Marek Web, who as a child had survived the war in the Soviet Union and lived with his parents in postwar Lodz, "Jews considered it as a relatively safe city. Postwar Poland wasn't a safe place, especially after the Kielce pogrom. Whoever didn't go abroad right away, hurried to Lodz." Indeed, in spite of rumors, threats and fears, pogrom-type events like those in Krakow or Kielce did not occur in Lodz. ${ }^{62}$

Jewish self-defense frameworks were organized in all major locations of Jewish population in Poland in the wake of the Kielce pogrom. They were headed and coordinated by the CKS, CCPJ's Centralna Komisja Specjalna, the Central Special Commission. A network of local Commissions existed 
for a while in various centers of Jewish population. The first chairman of the Central Special Commission was Antek Zuckerman. A report of the CKS states explicitly that "we had our people in factories, markets, schools and universities.” The Special Commission in Lodz included representatives of various Jewish organizations in town. It was headed by Arkadjusz Kahan and Jakob Szpigel. Kahan represented the Bund. Szpigel, a former Labor Union activist, had been a member of the Polish Communist Party before the war. According to Mirski, guards were assigned by the local Special Commission to the offices of the Jewish Committee, as well as to the various Zionist collectives, the kibbutzim, in town. The kibbutzim, according to Mirski, had also their own armed men. Some of the future members of the Haganah, the Jewish military underground in British ruled Palestine, started their training in the ranks of the Special Commission guards. The Lodz Bundists established their own self-defense units. Among the instructors were Marek Edelman and Yosl Zygelbojm, an ex-partisan and son of Artur Zygelbojm, a Bundist leader who had lived during the war in London and had committed suicide as a protest against the world's indifference to the Jewish tragedy. ${ }^{63}$

The Special Commission in Lodz started its activities shortly after the Kielce pogrom. During the next few months it acquired ninety-one weapons of various sorts. In October it had forty guards on its payroll, assigned to various Jewish locations throughout the city. Jewish institutions in Lodz were in possession of weapons and ammunition. Thus, the Bursa had 3 rifles and 1 sub-machine gun, the Helenowek Children's Home had 5 rifles and 3 sub-machine guns, the Poalei Zion collective had 3 rifles and 1 sub-machine gun. Jewish institutions in Lodz had a total of 17 rifles and 11 sub-machine guns. According to a September 1946 report of the Lodz Special Commission, 450 people were organized in several units. "The city has been divided into districts, and various CKS people are in charge of each one of them. Relations with the UB are good, and the Deputy Head of the Special Commission maintains continuous contact with them." The Commission also trained its people in the use of arms. The Lodz Commission report for the latter part of December 1946 stated: "The situation in Lodz is quiet on the whole. ORMO, Voluntary Reserves of the Citizens' Militia and MO, Citizens' Militia, check the streets, Jewish neighborhoods in particular. There were no anti-Jewish events. Due to the determined stand of the security authorities Jews are not afraid of disorders. We have daily contact with the Security Office." 64 


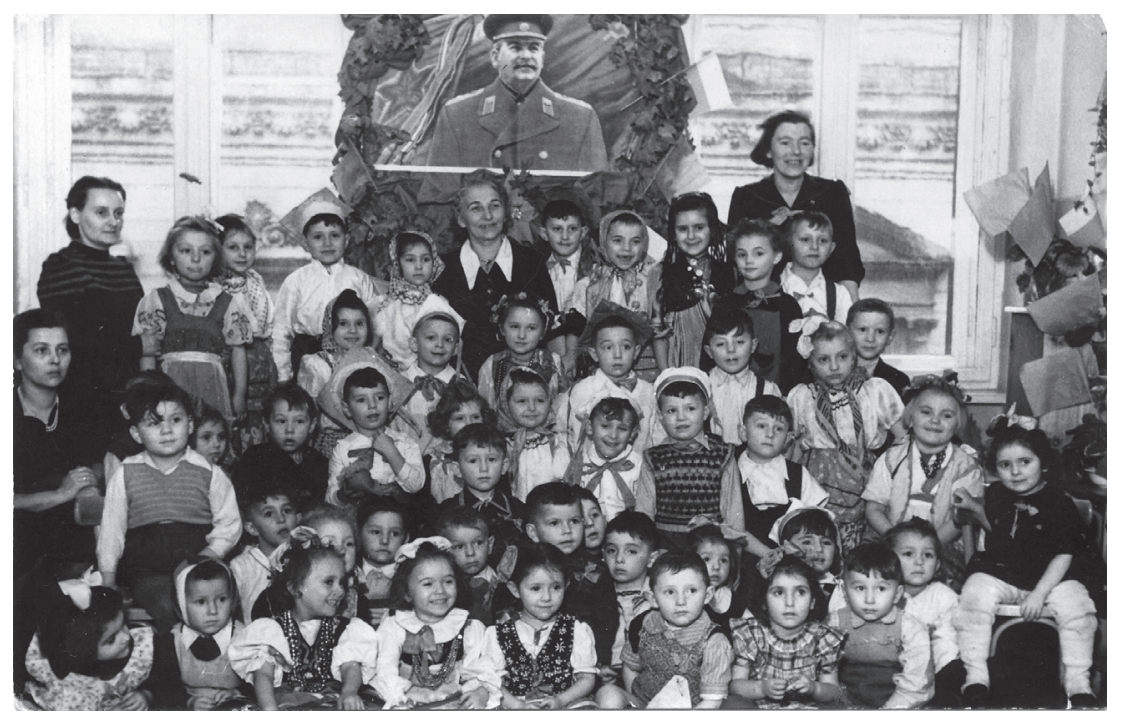

14. A kindergarten run by the Lodz Jewish Committee. Top right: Ewa FrenkelPrzemyslawski. Courtesy of Ewa Frenkel-Przemyslawski.

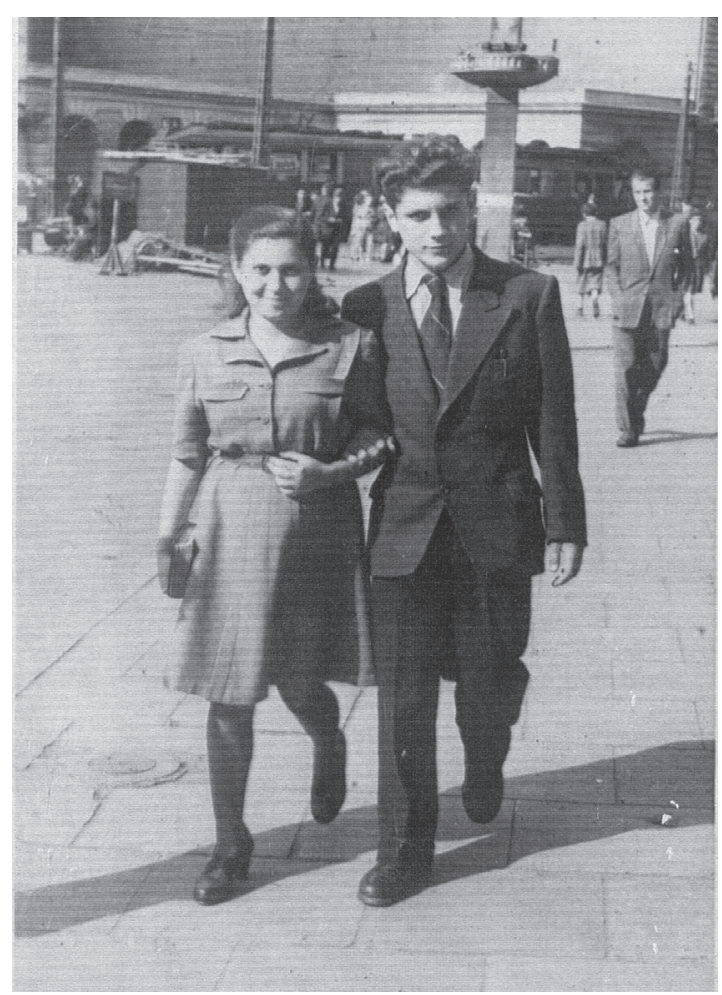

15. Aleks and Tosia Klugman. Lodz, 1946. Courtesy of the Klugmans. 


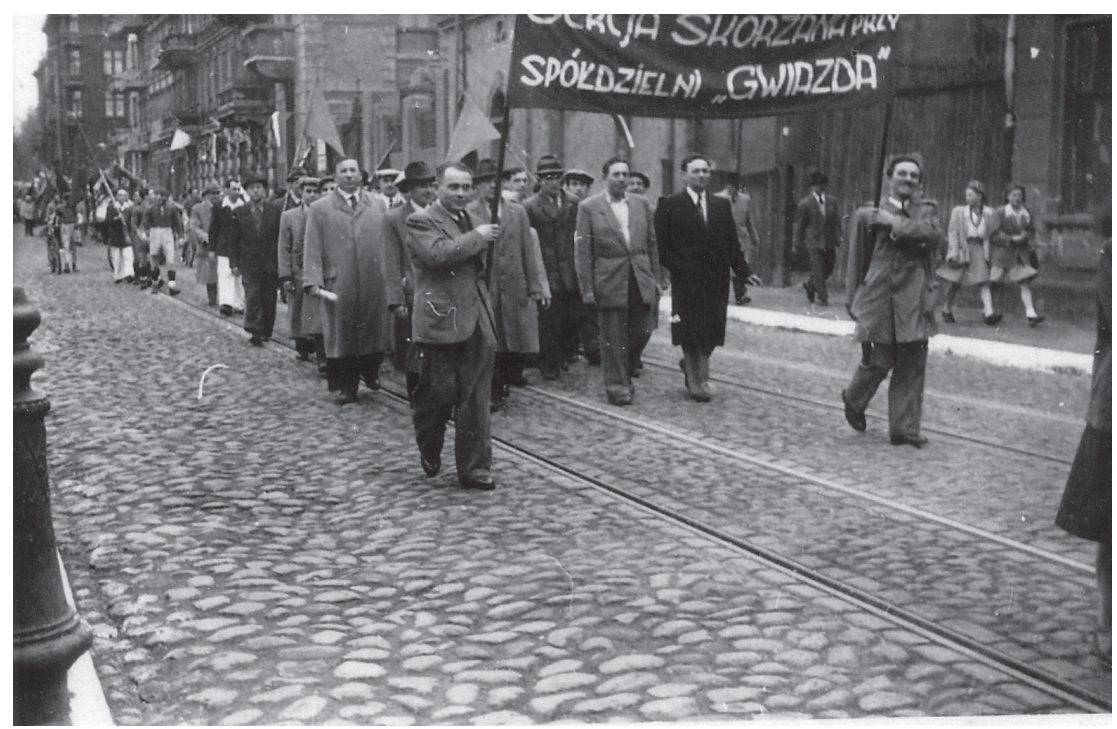

16. Members of a Jewish leather products cooperative in a 1st of May demonstration in postwar Lodz. Courtesy of Ewa Frenkel-Przemyslawski.

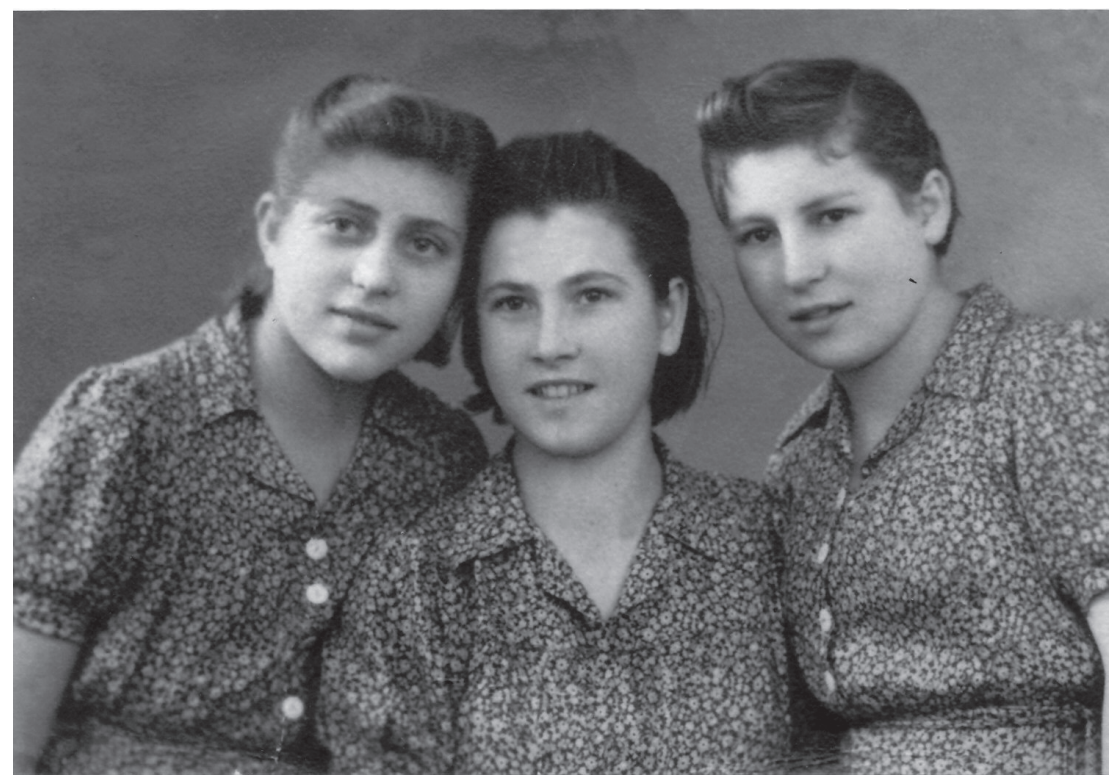

17. Young girls in the Jewish children's home in Helenowek, 1945. Courtesy of the Nitzbergs. 


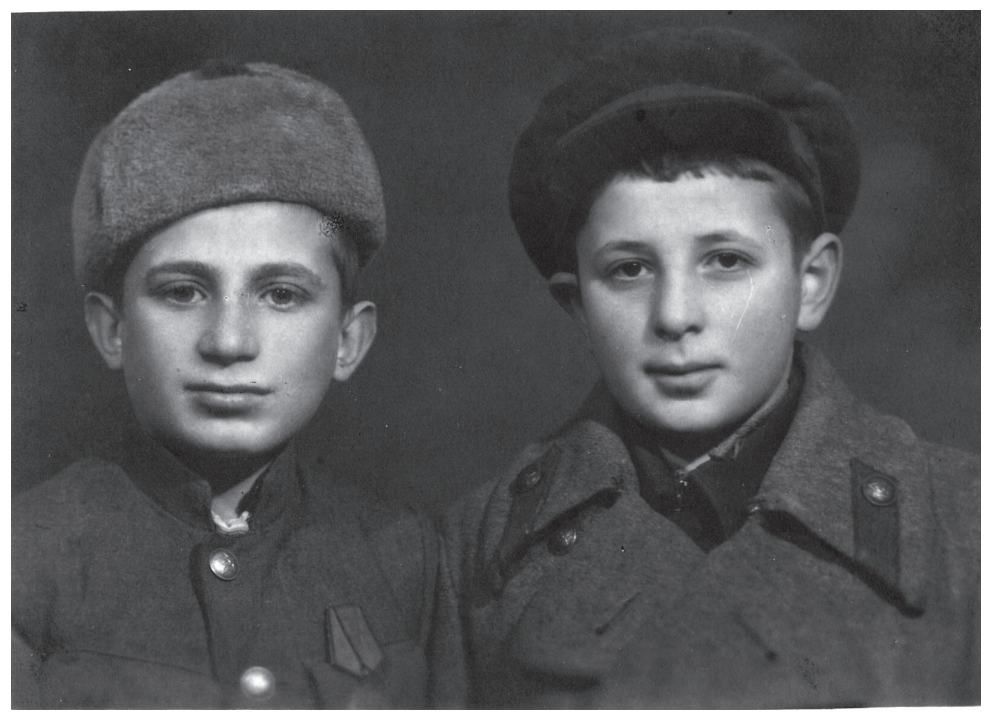

18. Children-partisans in the Jewish children's home in Helenowek. Courtesy of Dziunia Dublin.

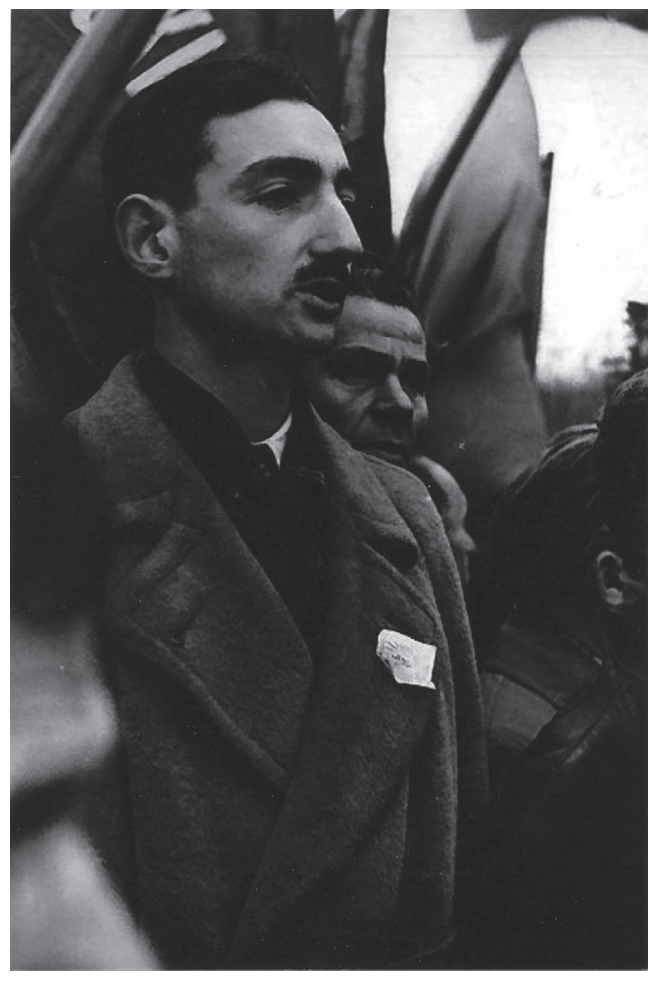

19. Marek Edelman at the funeral of the murdered Bundist Fishke Neiman. Lodz, June, 1946. Courtesy of Gazeta Wyborcza. 